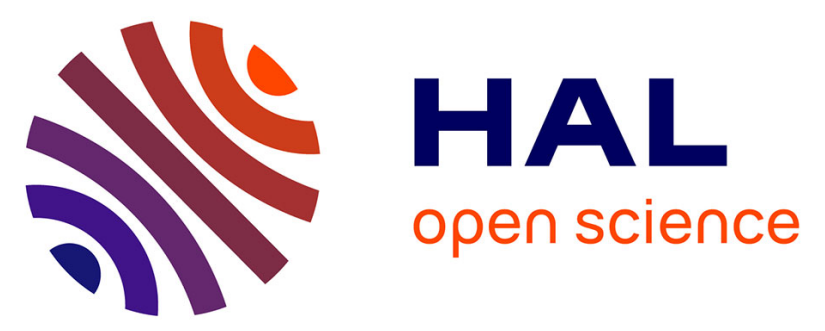

\title{
First evidence for a target site mutation in the EPSPS2 gene in glyphosate-resistant Sumatran fleabane from citrus orchards
}

\author{
Fidel González-Torralva, Javier Gil-Humanes, Francisco Barro, José \\ Domínguez-Valenzuela, Rafael Prado
}

\section{To cite this version:}

Fidel González-Torralva, Javier Gil-Humanes, Francisco Barro, José Domínguez-Valenzuela, Rafael Prado. First evidence for a target site mutation in the EPSPS2 gene in glyphosate-resistant Sumatran fleabane from citrus orchards. Agronomy for Sustainable Development, 2014, 34 (2), pp.553-560. 10.1007/s13593-013-0163-8 . hal-01234787

\section{HAL Id: hal-01234787 \\ https://hal.science/hal-01234787}

Submitted on 27 Nov 2015

HAL is a multi-disciplinary open access archive for the deposit and dissemination of scientific research documents, whether they are published or not. The documents may come from teaching and research institutions in France or abroad, or from public or private research centers.
L'archive ouverte pluridisciplinaire HAL, est destinée au dépôt et à la diffusion de documents scientifiques de niveau recherche, publiés ou non, émanant des établissements d'enseignement et de recherche français ou étrangers, des laboratoires publics ou privés. 


\title{
First evidence for a target site mutation in the EPSPS2 gene in glyphosate-resistant Sumatran fleabane from citrus orchards
}

\author{
Fidel González-Torralva • Javier Gil-Humanes • Francisco Barro • \\ José A. Domínguez-Valenzuela • Rafael De Prado
}

Accepted: 3 June 2013 / Published online: 4 July 2013

(C) INRA and Springer-Verlag France 2013

\begin{abstract}
The glyphosate herbicide has been extensively used for long time periods in woody crops to control a broad range of weeds. The rapid determination of resistant weeds in different woody crops could maintain the efficacy of herbicides and could improve weed management using rotating strategies. Unfortunately Sumatran fleabane has developed a resistance to glyphosate. The mechanism of resistance of Sumatran fleabane is unknown so far. Therefore, here, we studied the resistance of a Sumatran fleabane biotype collected from a citrus orchard, under greenhouse and laboratory conditions. Our results show a resistance factor of 7.4. The resistant biotype absorbed and translocated lower amounts of ${ }^{14} \mathrm{C}$-glyphosate compared to the susceptible biotype. Moreover, at the molecular level, the target site sequence of the EPSPS2 gene showed a Pro-182-Thr substitution in the resistant biotype. As a consequence, this biotype uses mechanisms of reduced absorption-translocation and target site mutation to resist against glyphosate. This is the first study to report the reduced absorption and a mutation in the EPSPS2 gene in the resistance mechanism in the Conyza genus.
\end{abstract}

Keywords Glyphosate resistance · Conyza sumatrensis . Absorption · Translocation - EPSPS2 - Target site mutation · Resistance mechanism

F. González-Torralva $(\bowtie) \cdot$ R. De Prado

Agricultural Chemistry and Soil Sciences, University of Córdoba, E-14071 Córdoba, Spain

e-mail: z82gotof@uco.es

J. Gil-Humanes • F. Barro

Institute for Sustainable Agriculture, Spanish National Research Council (IAS-CSIC), E-14080 Córdoba, Spain

J. A. Domínguez-Valenzuela

Agricultural Parasitology, Chapingo Autonomous University, 56230 Chapingo, México

\section{Introduction}

Conyza sumatrensis (Retz.) E. Walker (or Conyza albida Willd. ex Spreng.) is an annual to perennial dicot native to South America. This weed is important in crops with soil moisture, and together with Conyza canadensis (L.) Cronquist., it is considered to be the most widespread Conyza species in both agricultural and nonagricultural landscapes. C. sumatrensis is a highly invasive species because it produces a large amount of achenes, which exhibit rapid germination and a high dispersal capability (Hao et al. 2009). In southern Spain, C. sumatrensis (Fig. 1) has been found to mainly affect citrus orchards, where it is a difficult weed to control (Carretero 2004; Recasens and Conesa 2009). The most common, effective, and inexpensive method to control this invasive species is through the use of total herbicides such as glyphosate ( $\mathrm{N}$-(phosphonomethyl) glycine), which belongs to a chemical group of amino acid synthesis inhibitors. Following absorption, glyphosate is readily translocated with photosynthates from the leaves to the meristematic tissue (Franz et al. 1997). In susceptible plants, glyphosate inhibits the critical enzyme 5-enolpyruvylshikimate 3-phosphate synthase (EPSPS), which catalyzes phosphoenolpyruvate and shikimate-3-phosphate to form 5enolpyruvylshikimate 3-phosphate (EPSP) and inorganic phosphate, which ultimately results in plant death (Steinruecken and Amrhein 1980).

The adoption of this herbicide into a wide variety of cropping systems has unfortunately resulted in the appearance of 24 resistant species (11 dicots and 13 monocots) worldwide (Heap 2013). The first confirmed case of resistance against glyphosate in the Asteraceae family was $C$. canadensis, which was reported in 2001 (VanGessel 2001). In Spain, biotypes of Conyza bonariensis (L.) Cronquist., C. canadensis, and $C$. sumatrensis have been reported as glyphosate-resistant, and 


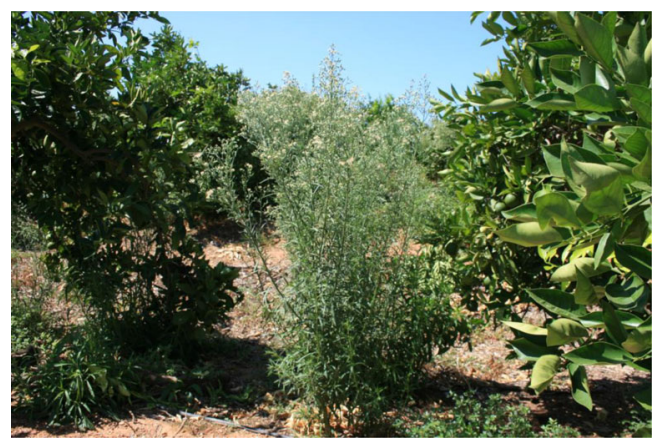

Fig. 1 Conyza sumatrensis plants affect a citrus orchard in Huelva, southern Spain. Note the size and vigor of this noxious species

with the exception of $C$. sumatrensis, the resistance mechanism has been previously described (Dinelli et al. 2008; GonzálezTorralva et al. 2012b).

Studies on the resistance mechanisms in $C$. bonariensis and $C$. canadensis from Spain, however, have shown increased EPSPS messenger ribonucleic acid levels and glyphosate metabolism in the resistant biotypes respectively, although reduced translocation of the herbicide to the remainder of the shoot and to the roots has been reported as the main resistance mechanism. This reduced translocation is most likely due to a rapid glyphosate sequestration into the vacuole, as previously reported in biotypes from the USA (Dinelli et al. 2008; Feng et al. 2004; Ge et al. 2010; González-Torralva et al. 2012b). In other glyphosate-resistant species, such as Amaranthus palmeri (S.) Wats., the amplification of the EPSPS gene has been reported as the main resistance mechanism. Moreover, in glyphosate-resistant grass weeds such as Lolium rigidum Gaudin., Lolium multiflorum Lam., Digitaria insularis (L.) Fedde., and Eleusine indica (L.) Gaertn., the resistance mechanisms were more complex and involved a mutation in the EPSPS gene, gene amplification, reduced translocation, and glyphosate metabolism (Baerson et al. 2002; Bostamam et al. 2012; De Carvalho et al. 2012; González-Torralva et al. 2012a; Salas et al. 2012). To date, the physical, physiological and molecular resistance mechanisms in Sumatran fleabane have not been reported.

Understanding the genetic basis of resistance and its evolution in different cropping systems is a fundamental key for integrated weed management, and consequently, a sustainable agriculture. The aim of this study was to investigate the resistance mechanisms against glyphosate in the C. sumatrensis biotype from southern Spain. Different studies exploring the physical (dose-response and spray retention assays), physiological (shikimic acid accumulation and absorption-translocation of ${ }^{14} \mathrm{C}$-glyphosate assays), and molecular factors were performed to elucidate the resistance mechanisms to this herbicide in this specific biotype.

\section{Materials and methods}

\subsection{Herbicides and reagents}

Glyphosate in its isopropylamine salt form (Roundup Energy $45 \% w / v)$ was supplied by Monsanto Agricultura España and used in all of the experiments described below. Radiolabeled herbicide ${ }^{14} \mathrm{C}$-glyphosate $\left(273.8 \mathrm{MBq} \mathrm{mmol}^{-1}\right.$ ) was supplied by American Radiolabeled Chemicals Incorporation (St. Louis, MO, USA) and was used exclusively in the absorption and translocation assays.

\subsection{Plant material and growing conditions}

In 2009, seed samples of $C$. sumatrensis that were suspected to be glyphosate resistant (labeled as R1, R2, and R3) were collected on a citrus farm located in Huelva, southern Spain, where glyphosate had been applied continuously for at least 10 years at $900 \mathrm{~g}$ active ingredient (ai) ha ${ }^{-1}$. Seeds of a susceptible (S) C. sumatrensis population were collected within the same region. Under greenhouse conditions, the S-biotype was completely controlled using $200 \mathrm{~g}$ ai ha ${ }^{-1}$ (González-Torralva et al. 2010).

Seeds from the S- and collected R-populations were sown in pots $(15 \mathrm{~cm}$ in diameter by $4.5 \mathrm{~cm}$ in height) that were filled with moistened peat and covered with a transparent film up to emergence. The seedlings were individually transplanted into $7 \times 7 \times 7 \mathrm{~cm}$ pots with a $1: 1(\mathrm{v} / \mathrm{v})$ mixture of peat-sandy soil and placed in a growth chamber at $28^{\circ} \mathrm{C} / 18^{\circ} \mathrm{C}$ (day/night), a 16-h photoperiod, $850 \mu \mathrm{mol} \mathrm{m} \mathrm{m}^{-2} \mathrm{~s}^{-1}$ photosynthetic photon flux density, and $80 \%$ relative humidity.

\subsection{Screening}

Plants of the R1, R2, and R3 biotypes at the Biologisehe Bundesanstalt fur Land- und Forstwirtschafl, Bun dessorenami and Chemical Industry (BBCH) 14-15 scale (Hess et al. 1997) were treated with $360 \mathrm{~g}$ ai ha ${ }^{-1}$ of glyphosate using a laboratory spray chamber equipped with flat fan nozzles (Tee Jet 8002 Even Flat Spray Tip) positioned at $50 \mathrm{~cm}$ above the plants and calibrated to spray $200 \mathrm{~L} \mathrm{ha}^{-1}$ at $200 \mathrm{kPa}$. A total of 20 plants were treated, and 5 plants were used as nontreated controls. Three weeks after treatment, the plants were cut at ground level, and the fresh weight was recorded and converted into a percentage of nontreated plants. The resistant population with the lowest fresh weight reduction with respect to the nontreated plants was considered as the R-biotype. Following the procedures described above, the R-biotype was reseeded, and an additional treatment was performed using $360 \mathrm{~g}$ ai ha ${ }^{-1}$ under the same conditions as previously described to collect the seeds and to perform all of the assays described below. 


\subsection{Dose-response assays}

Glyphosate was applied to the plants at the BBCH 14-15 scale in selected R- and S-biotypes under the same conditions as previously described. The doses ranged from 0 to $1,000 \mathrm{~g}$ ai ha ${ }^{-1}$ for the R-biotype and 0 to $300 \mathrm{~g} \mathrm{ai} \mathrm{ha}^{-1}$ for the S-biotype. Treatments were replicated five times in a completely randomized study design (each replication with three plants). Three weeks after treatment, the plants were harvested at ground level, and their fresh weight was recorded.

\subsection{Shikimic acid accumulation}

The shikimic acid extraction was made following the protocol as described by Cromartie and Polge (2000). Plants of both biotypes in the BBCH 14-15 scale were treated with glyphosate at a rate of $200 \mathrm{~g}$ ai ha ${ }^{-1}$. Fifty milligrams of treated and nontreated plant tissue was collected and frozen in liquid nitrogen at 24, 48, 72, 96, and $168 \mathrm{~h}$ after treatment. Shikimic acid accumulation was optically determined at $380 \mathrm{~nm}$ using a Beckman DU-640 spectrophotometer. The standard curve was run for nontreated plants and known concentrations of shikimic acid. The experiment consisted of five treated and three nontreated plants with three replicates. The results were expressed as $\mathrm{mg} \mathrm{g}^{-1}$ fresh weight.

\subsection{Spray retention assay}

The methodology described by González-Torralva et al. (2010) was followed. Plants of R- and S-biotypes at BBCH 14-15 scale were treated at the rate of $200 \mathrm{~g}$ ai ha ${ }^{-1}$ glyphosate $+100 \mathrm{mg} \mathrm{L}^{-1} \mathrm{Na}$-fluorescein. The spray chamber and conditions were as described above in the screening assay. After the spray solution had dried on the foliage $(\approx 20 \mathrm{~min}$ ), the plants were cut off at ground level and immersed in $50 \mathrm{~mL}$ of $5 \mathrm{mM} \mathrm{NaOH}$ solution for $30 \mathrm{~s}$. The rinsate of each plant was filtered and monitored at $490_{\mathrm{exc}} / 510_{\mathrm{em}} \mathrm{nm}$ with a Hitachi F-2500 Fluorescence Spectrophotometer. A calibration standard curve was constructed with serial dilutions of Na-fluorescein. Then, the plants were placed at $80^{\circ} \mathrm{C}$ for $72 \mathrm{~h}$, and the dry matter was recorded. Four replicates (three plants each) were made for each biotype. The results were expressed as $\mu \mathrm{L}$ spraying solution $\mathrm{g}^{-1}$ dry matter.

\subsection{Absorption and translocation of ${ }^{14} \mathrm{C}$-glyphosate}

The methodology described by González-Torralva et al. (2010) was followed. ${ }^{14} \mathrm{C}$-glyphosate was mixed with commercial formulated glyphosate to prepare a solution with a specific activity of $0.834{\mathrm{kBq} \mu \mathrm{L}^{-1} \text { and a rate of } 200 \mathrm{~g} \text { ai ha }}^{-1}$. The plants of R- and S-biotypes in BBCH 14-15 scale were treated with the radiolabeled herbicide applying one droplet of $1.0 \mu \mathrm{L}$ on the adaxial surface of the third leaf in each plant using a micropipette. The unabsorbed ${ }^{14} \mathrm{C}$-glyphosate in the treated leaf was removed with $3 \mathrm{~mL}$ of a $1: 1 \mathrm{v} / \mathrm{v}$ wateracetone solution after $12,24,48,72$, and $96 \mathrm{~h}$ of droplet application. The plants were separated into treated leaf, rest of the shoot, and root, and then placed into cellulose cones. The rinsate was mixed with $7 \mathrm{~mL}$ of scintillation liquid and analyzed by liquid scintillation spectrometry (Scintillation Counter LS 6500, Beckman Coulter). Plant tissue was dried at $60{ }^{\circ} \mathrm{C}$ for $72 \mathrm{~h}$ and combusted in a biological sample oxidizer (307, PerkinElmer). The ${ }^{14} \mathrm{CO}_{2}$ was trapped and counted in $18 \mathrm{~mL}$ of a 9:9v/v mixture of Carbo-Sorb ${ }^{\circledR} \mathrm{E}$ and Permafluor $^{\circledR}$ (PerkinElmer). The experiment consisted of six replicates.

\subsection{Phosphor imaging}

The plants were treated as described for absorption and translocation assays. Whole plants were gently rinsed, pressed, and dried at room temperature ( $\approx 6$ days) and then placed adjacent to a $25 \times 12.5 \mathrm{~cm}$ phosphor storage film for $6 \mathrm{~h}$. The film was then scanned for radiolabel dispersion in a storage phosphor system (Cyclone, PerkinElmer). The experiment was realized using three biological samples per biotype and harvest time.

\subsection{EPSPS2 gene sequencing}

Total ribonucleic acid (RNA) was extracted from $0.1 \mathrm{~g}$ of young leaf tissue collected from the S- and R-biotypes at BBCH 14-15 scale. The total RNA isolation was performed according to the standard phenol and guanidine isothiocyanate extraction methodology (TRIzol ${ }^{\circledR}$ Reagent; Invitrogen, CA, USA) and treated with TURBO DNase ${ }^{\circledR}$ (RNase-Free; Ambion, Warrington, UK) to eliminate any potential deoxyribonucleic acid (DNA) contamination. The resulting RNA was immediately stored at $-80{ }^{\circ} \mathrm{C}$. First strand complementary DNA (cDNA) synthesis was performed using $2 \mu \mathrm{g}$ of previously isolated total RNA and Moloney murine leukemia virus reverse transcriptase (Invitrogen) in combination with oligo (dT) ${ }_{12-18}$ and random nonamers (Amersham Biosciences, Amersham, UK) according to the manufacturer's instructions. Two pairs of primers were designed based on the EPSPS2 gene sequence of $C$. sumatrensis (GenBank accession number AY834205.1). Both pairs of primers amplified two partially overlapping sequences: F1 EPSPS2 (5' TCTAAAGCTCCAGAAG AAATTGTG 3') and R1 EPSPS2 (5' GAAACCCCA AACCGTYCC $3^{\prime}$ ) amplified a 674 bp fragment; F2 EPSPS2 (5' TGTCAGGATCTATAAGTAGTCA 3') and R2 EPSPS2 (5' ATGCTTAGTGTATCTTTCAAG 3'), which amplified an 815 bp fragment. In total, a 1,293 bp fragment of the coding sequence of the EPSPS gene was covered by both polymerase chain reactions (PCRs). Each PCR was performed in duplicate 
using the cDNA obtained from $50 \mathrm{ng}$ of total RNA, $2 \mathrm{mM}$ $\mathrm{MgCl}_{2}, 0.2 \mathrm{mM}$ dNTP, $0.2 \mu \mathrm{M}$ of each primer, $1 \times$ buffer, and 0.625 units of a 100:1 enzyme mixture of nonproofreading (Thermus thermophilus) and proofreading (Pyrococcus furiosus) polymerases (BIOTOOLS, Madrid, Spain) in a final volume of $25 \mu \mathrm{L}$. The PCR conditions were as follows: $94^{\circ} \mathrm{C}$ 5 min, 35 cycles of $94{ }^{\circ} \mathrm{C} 30 \mathrm{~s}, 54{ }^{\circ} \mathrm{C} 30 \mathrm{~s}$, and $72{ }^{\circ} \mathrm{C} 50 \mathrm{~s}$; a final extension cycle of $72{ }^{\circ} \mathrm{C}$ was done for $10 \mathrm{~min}$. In addition, $10 \mu \mathrm{L}$ of the PCR product was loaded on to a $1 \%$ agarose gel, and the remainder of the product was purified using ExoSAP-IT ${ }^{\circledR}$ for PCR Product Clean-Up (USB, $\mathrm{OH}, \mathrm{USA}$ ) according to the manufacturer's instructions. The purified PCR products were then sequenced using the SCAI (University of Córdoba) DNA sequencing service. Three biological samples were used per biotype.

\subsection{Statistical analyses}

Data obtained from the dose-response assays were expressed as the percentage of weight reduction with respect to the nontreated control plants and were then pooled and fitted into a nonlinear, log-logistic regression model:

$Y=c+\left\{(d-c) /\left[1+(x / b)^{b}\right]\right\}$.

In this model, the fresh above-ground weight expressed as the percentage of the nontreated plants was represented by $Y$; the lower and upper asymptotes were represented by the coefficients $c$ and $d$. The slope of the line was represented by $b$; the $\mathrm{ED}_{50}$ (herbicide rate inhibiting plant growth by $50 \%$ ) was represented by $g$ (herbicide rate at the point of inflection halfway between the upper and lower asymptotes), and $x$ was the independent variable, i.e., herbicide rate. Regression analysis was performed using the SigmaPlot 10.0 software (Systat Software Inc.). The resistance factor (RF) was obtained by dividing the $\mathrm{ED}_{50}$ value of the R-biotype by the $\mathrm{ED}_{50}$ of the S-biotype.

In the absorption-translocation assays, the radioactivity was quantified using liquid scintillation spectrometry, and the herbicide absorbed was expressed as the percentage of kilobecquerel in the combusted tissue divided by the kilobecquerel in the combusted tissue+kilobecquerel in the leaf washes.

Statistical analyses which evaluated the differences between the R- and S-biotypes in the spray retention, shikimic acid accumulation, and absorption-translocation of ${ }^{14} \mathrm{C}$ glyphosate were performed using the Statistix version 8.0 Analytical Software. The data were subjected to analysis of variance (ANOVA), and the means were compared when necessary using Tukey's honestly significant difference test at the $5 \%$ probability.

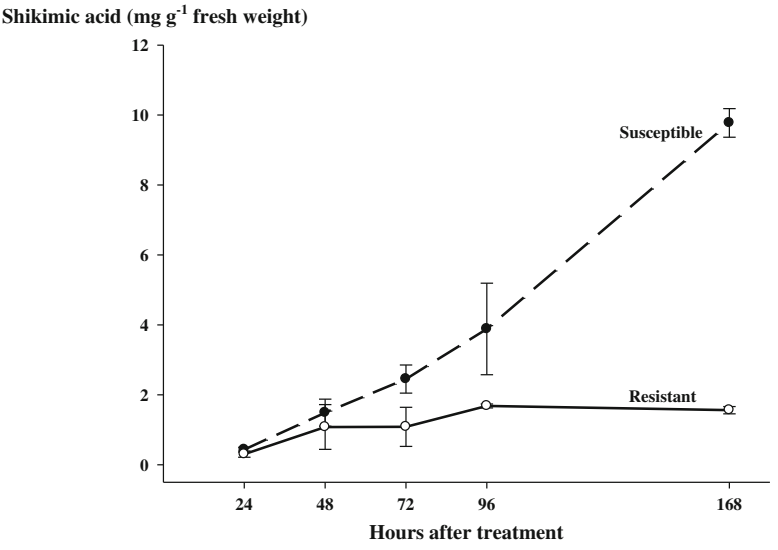

Fig. 2 Shikimic acid accumulation in glyphosate-resistant Conyza sumatrensis and its susceptible biotypes. The plants were treated at $200 \mathrm{~g}_{\text {ai ha }}{ }^{-1}$. The vertical bars represent \pm the standard errors of the mean

\section{Results and discussion}

\subsection{Screening and dose-response assays}

The collected samples showed a differential response to the glyphosate herbicide. The fresh weight reduction ranged from 36.14 to $81.70 \%$ (no further details). Due to the reduced fresh weight reduction of the R1 biotype (36.14\%), it was selected for use in all of the experiments described below following the selection process as explained in the "Screening" section. The fresh weight reduction (\%) in both the $C$. sumatrensis biotypes increased as the rate of glyphosate increased. The doseresponse assays showed a much higher susceptibility in the S-biotype compared to the R-biotype. In addition, the $\mathrm{ED}_{50}$ value was 7.4 times greater for the R-biotype $\left(177.1 \mathrm{~g} \mathrm{ai} \mathrm{ha}^{-1}\right) \mathrm{com}$ pared to the S-biotype $\left(\mathrm{ED}_{50}=23.8 \mathrm{~g}\right.$ ai ha $\left.{ }^{-1}\right)$ (figure not shown).

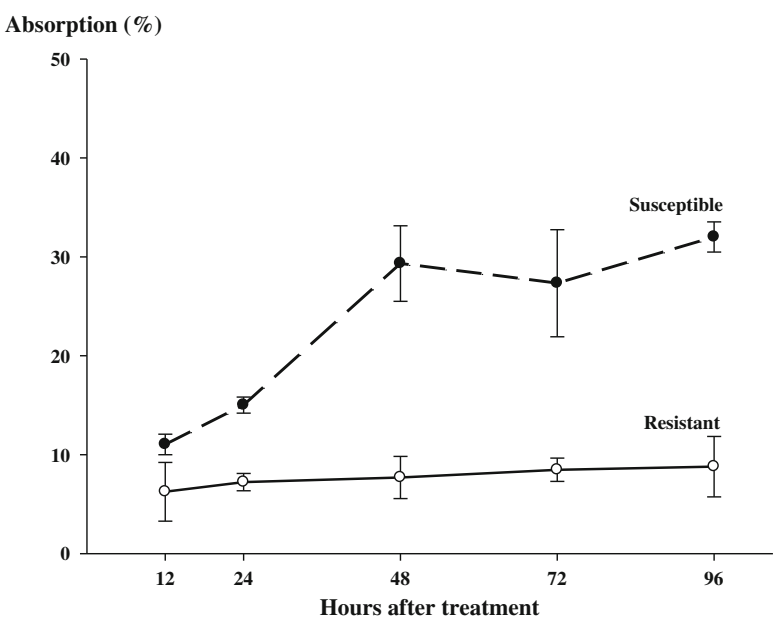

Fig. 3 Temporal absorption pattern of ${ }^{14} \mathrm{C}$-glyphosate in glyphosate resistant and susceptible biotypes of Conyza sumatrensis. The vertical bars represent \pm the standard errors of the mean 
Table 1 Translocation (percentage of absorbed radioactivity) of

${ }^{14} \mathrm{C}$-glyphosate to the rest of the shoot and to the roots in susceptible (S) and resistant (R) biotypes of Conyza sumatrensis

${ }^{a}$ The means within a column indicated by the same letter are not significantly different at the $5 \%$ level, as determined by the

Tukey's test. Mean values \pm standard error of the means are in parentheses

\begin{tabular}{llllllll}
\hline Hours after treatment & Biotype & Treated leaf & & \multicolumn{2}{l}{${\text { Rest of } \operatorname{shot}^{\mathrm{a}}}^{\mathrm{a}}$} & Root $^{\mathrm{a}}$ & \\
\hline 12 & $\mathrm{~S}$ & $78.3(1.0)$ & $\mathrm{B}$ & $7.2(0.7)$ & $\mathrm{D}$ & $14.3(0.2)$ & $\mathrm{CD}$ \\
& $\mathrm{R}$ & $90.1(1.1)$ & $\mathrm{A}$ & $6.5(1.9)$ & $\mathrm{D}$ & $3.3(0.7)$ & $\mathrm{E}$ \\
24 & $\mathrm{~S}$ & $75.6(3.1)$ & $\mathrm{BC}$ & $9.6(1.6)$ & $\mathrm{BCD}$ & $14.7(2.9)$ & $\mathrm{CD}$ \\
& $\mathrm{S}$ & $81.3(2.9)$ & $\mathrm{B}$ & $9.3(1.4)$ & $\mathrm{CD}$ & $9.3(1.4)$ & $\mathrm{DE}$ \\
& $\mathrm{R}$ & $63.5(2.7)$ & $\mathrm{DE}$ & $14.1(1.3)$ & $\mathrm{ABC}$ & $22.2(1.2)$ & $\mathrm{B}$ \\
72 & $\mathrm{~S}$ & $68.9(0.3)$ & $\mathrm{CD}$ & $14.5(0.8)$ & $\mathrm{ABC}$ & $16.5(0.1)$ & $\mathrm{BC}$ \\
& $\mathrm{R}$ & $56.9(1.0)$ & $\mathrm{E}$ & $8.9(0.4)$ & $\mathrm{CD}$ & $34.0(3.2)$ & $\mathrm{A}$ \\
& $\mathrm{S}$ & $68.3(2.1)$ & $\mathrm{CD}$ & $16.2(2.1)$ & $\mathrm{AB}$ & $15.4(1.5)$ & $\mathrm{BCD}$ \\
& $\mathrm{R}$ & $55.5(1.9)$ & $\mathrm{E}$ & $10.4(2.9)$ & $\mathrm{BCD}$ & $34.0(1.5)$ & $\mathrm{A}$ \\
& $\mathrm{S}$ & $61.4(2.4)$ & $\mathrm{DE}$ & $20.5(2.0)$ & $\mathrm{A}$ & $17.9(1.3)$ & $\mathrm{BC}$ \\
\hline
\end{tabular}

The dose response assays, which describe the growth reduction as a function of the herbicide rate, constitute one of the most accurate methods used to determine the herbicide efficacy. The RF (7.4) obtained in this study was similar to that previously reported by other investigations, in which glyphosate-resistant biotypes of $C$. bonariensis and $C$. canadensis showed RF values within the range of 6 to 13 (González-Torralva et al. 2012b; VanGessel 2001; Walker et al. 2011). In other species, such as L. multiflorum and $D$. insularis, the reported RF values were within the range of 3-5 (De Carvalho et al. 2011; González-Torralva et al. 2012a). This result confirmed the resistance of the R-biotype of $C$. sumatrensis to the herbicide glyphosate.

\subsection{Spray retention assay}

The spray retention quantifies the amount of herbicide solution that could penetrate into the plant, being an indicator of herbicide efficacy and selectivity in weed species. Changes in leaf morphology or the cuticle could affect the amount of herbicide solution that the plant received, and consequently, the Rbiotype could survive because of the lower retention of herbicide solution with respect to the S-biotype (Feng et al. 2004; Michitte et al. 2007; Wang and Liu 2007). However, in our assays, we did not find any effect of the biotype on spray retention (ANOVA, $P=0.3996)$, the R- and S-biotypes retained $556( \pm 45)$ and $484 \mu \mathrm{L}( \pm 84.7)$ spraying solution $\mathrm{g}^{-1}$ dry matter, respectively. The same conclusion was reported in $C$. canadensis from USA and Spain (Feng et al. 2004; González-Torralva et al. 2012b). Nevertheless, in a glyphosate-resistant $L$. multiflorum population from Chile, the spray retention was significantly lower in the R-biotype with respect to the S-biotype (Michitte et al. 2007).

\subsection{Shikimic acid accumulation}

Excluding tolerant and genetically manipulated plants (Pline et al. 2002), susceptible plants tend to accumulate more shikimic acid compared to resistant plants after glyphosate application. In our assays, the S-biotype accumulated more shikimic acid over time compared to the R-biotype. At 24 and $48 \mathrm{~h}$ after treatment, both biotypes accumulated similar amounts of shikimate (Fig. 2). However, at $72 \mathrm{~h}$ after treatment, the S-biotype began to accumulate more shikimic acid than the R-biotype, although this difference was not significant according to an ANOVA test. However, at 96 and $168 \mathrm{~h}$ after treatment, significant differences were found between the biotypes; at $168 \mathrm{~h}$ after treatment, the S-biotype had accumulated 6.2 times more shikimate than the R-biotype (Fig. 2).

In some cases, a similar accumulation was found between the biotypes after a specific duration of glyphosate treatment. However, at the end, the accumulation of shikimic acid in the R-plants decreases to basal levels, while in the S-biotype,
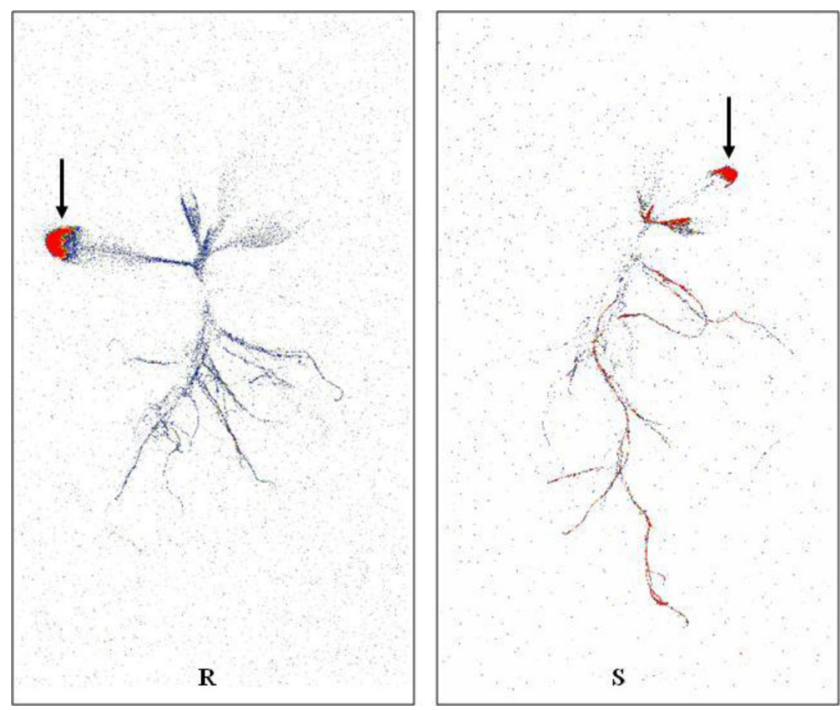

Fig. 4 Representative phosphor images demonstrating movement of ${ }^{14} \mathrm{C}$-glyphosate in resistant $(\mathrm{R})$ and susceptible (S) Conyza sumatrensis plants at $96 \mathrm{~h}$ after treatment. The intensity of the red color corresponds to higher concentrations of ${ }^{14} \mathrm{C}$-glyphosate. The arrows indicate the initial drop application site 
the accumulation of shikimic acid increases until plant death (Chodova et al. 2009; González-Torralva et al. 2012b). These results indicated that shikimic acid showed a differential accumulation over time between the R- and S-plants, which indicated that the EPSPS enzyme was still affected by the herbicide activity.

\subsection{Absorption and translocation of ${ }^{14} \mathrm{C}$-glyphosate}

Herbicide absorption is one of the most studied resistance mechanisms. Not many species have evolved resistance to glyphosate with only this mechanism, but for instance, in the glyphosate-resistant species L. multiflorum and Sorghum halepense (L.) Pers., a reduced absorption has been reported to contribute to resistance (Michitte et al. 2007; Vila-Aiub et al. 2012). In our assays, the R- and S-biotypes showed a differential pattern of absorption of ${ }^{14} \mathrm{C}$-glyphosate, with the S-biotype absorbing significantly larger percentages of herbicide $24 \mathrm{~h}$ after treatment onwards (Fig. 3). At 48, 72, and $96 \mathrm{~h}$ after treatment, the S-biotype absorbed 3.8, 3.2, and 3.6 times more ${ }^{14} \mathrm{C}$-glyphosate than the R-biotype, respectively (Fig. 3). Following absorption, the translocation of the herbicide also showed differences between both biotypes. The S-biotype was able to translocate glyphosate to the roots more rapidly than the R-biotype. For instance, at $12 \mathrm{~h}$ after treatment, the Sbiotype had translocated $14.3 \%$ of the absorbed herbicide from the treated leaf to the roots, whereas the R-biotype had only translocated $3.3 \%$ within the same time frame (Table 1 ). Differences between the biotypes in herbicide translocation to the remainder of the shoot and to roots at 72 and $96 \mathrm{~h}$ after

A. thaliana
S. halepense
Z. mays
S
R

A. thaliana

S. halepense

Z. mays

$\mathrm{S}$

$\mathbf{R}$
A. thaliana
S. halepense
Z. mays
$\mathrm{S}$
R
A. thaliana
S. halepense
z. mays
$\mathrm{S}$
R
A. thaliana
S. halepense
$Z$. mays
$\mathrm{S}$
R
A. thaliana
S. halepense
z. mays
$\mathrm{S}$
R

A. thaliana

S. halepense

z. mays

$\mathrm{S}$

R

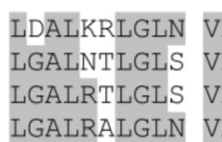

VETDSENNRA VEADKVAKRA VEADKAAKRA VEENAAIKRA VEENAAIKRA LGALRALGLN GGNASYVLDG
GGNATYVLDG
GGNATYVLDG
GGNSSYVLDG
GGNSSYVLDG VPRMRERPIG VPRMRERPIG VPRMRERPIC VPRMRERPIC VPRMRERPIG

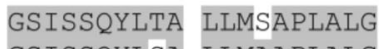
GSISSQYLSA LLMAAPLALG GSISSQYLSA LLMAAPLALC GSISSQYLTS LLMAAPLALG GSISSQYLTS

LLMAAPLALC$$
\begin{array}{ll}
\text { EHSDSWDRFF } & \text { VK } \\
\text { EHSDSWDRFY } & \text { IK } \\
\text { EHSDSWDRFY } & \text { IKG } \\
\text { EHSDTWDRFY } & \text { VRG } \\
\text { EHSDTWDRFY VRG }
\end{array}
$$$$
\text { VKGGQKYKSP GNAYVEGDAS }
$$$$
\text { IKGGQKYKSP KNAYVEGDAS }
$$$$
\text { IKGGQKYKSP KNAYVEGDAS }
$$

VRGGQKYKSP GNAYVEGDAS

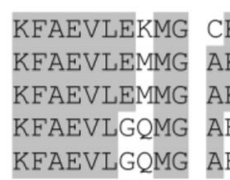

CKVSWTENSV

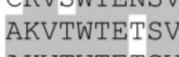

TVTGPPRDAF

\begin{tabular}{|c|c|c|}
\hline PTTI & WRVKETERMI & \\
\hline JAS & WRVKETERMV & Li \\
\hline GPTAIRDVAS & WRVKETERMV & \\
\hline$F \perp A \perp$ & WRVKETERMI & CIE \\
\hline & WRVKETERMI & AICTELI \\
\hline & ADVPITI & $\mathrm{CH}^{\prime}$ \\
\hline & AEVPVTIR & CTRKTH \\
\hline & AEVPVTIR & $>5$ \\
\hline & AEVPVTI & $\mathrm{TH}$ \\
\hline & FVPVTT & גז \\
\hline
\end{tabular}

VVEGCGGIFP
VVVGCGGKFP
VVVGCGGKFP

VVVGCGGKFP V-EDAKEEVQ

IVEGCGGVFP VGKEAKDEIQ

DLVVGLKQLG ADVECTLGT DLVVGLKQLG

DLVVGLKQLC

DLVTGLKQLG

DLVTGLKQLG

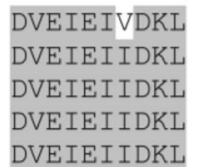

SACYFLAGAA
SASYFLAGAA
SASYFLAGAA

SASYFLAGAA

SASYFLAGAA

ADVDCFLGTD

ADVDCFLGTD

ANVDCSLGTN

ANVDCSLGTN

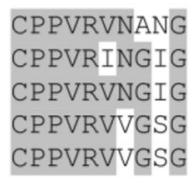

240

GMRHLRAIDV

ISVPYVEMT

ISIPYVEMTL

ISIPYVEMTL

ISVPYVEMTI

ISVPYVEMTI

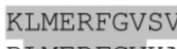

RLMERFGVKA

RLMERFGVKA

KLMERFGVSV

KLMERFGVSV

ITGETVTVEG

ITGGTVTVEG

CGTTSLQGDV

CGTTSLQGDV

CGTTSLQGDV

ITGGTVTVEG CGTSSLQGDV

ITGGTVTVEG CGTSSLQGDV

360

180

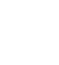
60

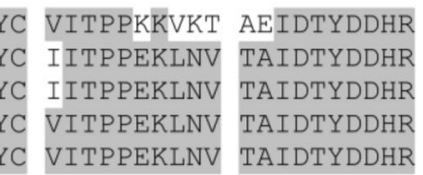

510
Fig. 5 Partial protein sequence alignment of the EPSPS2 gene of resistant (R) and susceptible (S) Conyza sumatrensis plants. The box shows a proline $(\mathrm{P})$ to threonine $(\mathrm{T})$ substitution at position 182 (amino acid number based on the start codon (ATG) of Arabidopsis thaliana (GenBank:CAA29828.1) EPSP sequence). Additionally, an EPSPS
Sorghum halepense (GenBank:AEP26127.1) and a Zea mays (GenBank:X63374.1) sequence were used to compare the EPSPS gene. The highlighted color indicates homology among the different sequences 
treatment were significant (Table 1). At $96 \mathrm{~h}$ after treatment, the S-biotype moved more than $34 \%$ of the absorbed glyphosate to the roots, while the R-biotype only translocated $17 \%$ to this organ (Table 1). In contrast, the translocation of glyphosate to the rest of the shoot was more efficient by the R-biotype. These results confirmed a reduced absorption and translocation of ${ }^{14} \mathrm{C}$-glyphosate in the R-biotype. Assays performed on $C$. canadensis (USA and Spain) and $C$. bonariensis (Spain), as well as L. multiflorum showed that the absorption did not contribute to the glyphosate resistance in these biotypes (Dinelli et al. 2008; Feng et al. 2004; González-Torralva et al. 2012b).

Once glyphosate is absorbed, it is extensively translocated through the phloem to the apical meristems in the shoot and roots. The translocation of glyphosate is both acropetal and basipetal from the treated foliage (Franz et al. 1997). Extensive studies performed worldwide have shown that reduced translocation was most likely the main resistance mechanism in various glyphosate-resistant biotypes of species such as $C$. canadensis, $C$. bonariensis, $L$. multiflorum, $L$. rigidum, and $S$. halepense, where the movement of the herbicide was impaired in the R-biotypes with respect to the S-biotype (Feng et al. 2004; Vila-Aiub et al. 2012; Yu et al. 2009). The reduced translocation found in this biotype was most likely due to the glyphosate sequestration into the cell vacuoles as demonstrated in the $C$. canadensis biotype from USA (Ge et al. 2010) and Lolium spp. from different countries, where vacuole sequestration was the major resistance mechanism in this genus (Ge et al. 2012).

\subsection{Phosphor imaging}

The translocation of the absorbed herbicide was visualized using phosphor imaging. Visually, at $96 \mathrm{~h}$ after droplet application, glyphosate translocation from the treated leaf to the rest of the shoot and roots was more evident in the S-biotype (Fig. 4, right). In the resistant biotype, the glyphosate absorbed remained mainly in the treated leaf, and only small amounts were translocated to the remainder of the plant (Fig. 4, left).

\subsection{EPSPS2 gene sequencing}

A total of 1,287 bp of the EPSPS2 gene of the $\mathrm{S}$ and $\mathrm{R} C$. sumatrensis plants were sequenced. The cDNA and its predicted protein were searched using the Basic Local Alignment Search Tool for nucleotides and protein algorithms (http://blast.ncbi.nlm.nih.gov/), respectively. The results showed a high homology with the $C$. sumatrensis (GenBank:AY834205.1) and C. bonariensis (GenBank: EF200073.1) EPSPS sequences. The R and S proteins were aligned and numbered based on a published EPSPS sequence of Arabidopsis thaliana (L.) Heynh. (GenBank:
CAA29828.1). Moreover, these proteins were compared with the EPSPS protein sequence of $S$. halepense (GenBank: AEP26127.1) and Zea mays (L.) (GenBank:X63374.1). A comparison between the $\mathrm{R}$ and $\mathrm{S}$ proteins showed an amino acid substitution at position 182 (amino acid number based on the start codon (ATG) of the $A$. thaliana EPSPS sequence) consisting of a proline to threonine conversion in the R-biotype (Fig. 5).

Target site mutations, particularly for glyphosate in the amino acid Pro-106, have been well documented to confer a specific resistance level in different species such as $L$. rigidum, L. multiflorum, or E. indica (Baerson et al. 2002; Bostamam et al. 2012). In D. insularis, the same amino acid substitution was reported at position 182 with respect to the EPSPS A. thaliana sequence (De Carvalho et al. 2012). This is the first time that a mutation in the target site is reported in a glyphosate-resistant Conyza species. In other assays performed using the EPSPS1 and EPSPS2 homologue genes in horseweed (C. canadensis), no amino acid changes occurred when the EPSPS fragment sequences of R- and S-biotypes were compared (Chodova et al. 2009; Nol et al. 2012).

\section{Conclusion}

In woody crops, the incorporation of other techniques to control weeds to avoid relying solely on herbicides will ensure a major diversity of the ecosystem, and consequently, the selective pressure exerted on the weeds and the appearance of resistant species will be minor and will additionally preserve a valuable molecule such as glyphosate. This is the first study to describe the resistance mechanism of $C$. sumatrensis, and it is also the first report to detect a mutation in the resistant biotype in this genus.

Acknowledgments The Monsanto Company and Spain's MICINN Project (AGL2010-16774) supported this research. The authors thank Professor Fernando Bastida from Huelva University for his help in improving this manuscript and to Rafael Roldán-Gómez and Isabel M. Algaba García for technical assistance.

\section{References}

Baerson SR, Rodriguez DJ, Tran M, Feng Y, Biest NA, Dill GM (2002) Glyphosate-resistant goosegrass. Identification of a mutation in the target enzyme 5-enolpyruvylshikimate-3-phosphate synthase. Plant Physiol 129:1265-1275. doi:10.1104/pp. 001560

Bostamam Y, Malone JM, Dolman FC, Boutsalis P, Preston C (2012) Rigid ryegrass (Lolium rigidum) populations containing a target site mutation in EPSPS and reduced glyphosate translocation are more resistant to glyphosate. Weed Sci 60:474-479. doi:10.1614/ WS-D-11-00154.1

Carretero JL (2004) Flora arvense Española. Las malas hierbas de los cultivos Españoles. Phytoma, Valencia 
Chodova D, Salava J, Martincová O, Cvikrova M (2009) Horseweed with reduced susceptibility to glyphosate found in the Czech Republic. J Agric Food Chem 57:6957-6961. doi:10.1021/jf901292x

Cromartie TH, Polge ND (2000) An improved assay for shikimic acid and its use as a monitor for the activity of sulfosate. Proc Weed Sci Soc Am 40:291

De Carvalho LB, Cruz-Hipolito H, González-Torralva F, Da Costa Aguiar Alves PL, Christoffoleti PJ, De Prado R (2011) Detection of sourgrass (Digitaria insularis) biotypes resistant to glyphosate in Brazil. Weed Sci 59:171-176. doi:10.1614/WS-D-10-00113.1

De Carvalho LB, Alves PLDCA, González-Torralva F, Cruz-Hipolito HE, Rojano-Delgado AM, De Prado R, Gil-Humanes J, Barro F, Luque De Castro MD (2012) Pool of resistance mechanisms to glyphosate in Digitaria insularis. J Agric Food Chem 60:615-622. doi:10.1021/jf204089d

Dinelli G, Marotti I, Bonetti A, Catizone P, Urbano JM, Barnes J (2008) Physiological and molecular bases of glyphosate resistance in Conyza bonariensis biotypes from Spain. Weed Res 48:257-265. doi:10.1111/j.1365-3180.2008.00623.x

Feng PCC, Tran M, Chiu T, Sammons RD, Heck GR, Cajacob CA (2004) Investigations into glyphosate-resistant horseweed (Conyza canadensis): retention, uptake, translocation, and metabolism. Weed Sci 52:498-505. doi:10.1614/WS-03-137R

Franz JE, Mao MK, Sikorski JA (1997) Glyphosate: a unique global herbicide. ACS, Washington

Ge X, d'Avignon DA, Ackerman JJH, Douglas Sammons R (2010) Rapid vacuolar sequestration: the horseweed glyphosate resistance mechanism. Pest Manag Sci 66:345-348. doi:10.1002/ps.1911

Ge X, D'Avignon DA, Ackerman JJH, Collavo A, Sattin M, Ostrander EL, Hall EL, Sammons RD, Preston C (2012) Vacuolar glyphosatesequestration correlates with glyphosate resistance in ryegrass (Lolium spp.) from Australia, South America, and Europe: a 31P NMR investigation. J Agric Food Chem 60:1243-1250. doi:10.1021/j2203472s

González-Torralva F, Cruz-Hipolito H, Bastida F, Mülleder N, Smeda RJ, De Prado R (2010) Differential susceptibility to glyphosate among the Conyza weed species in Spain. J Agric Food Chem 58:4361-4366. doi:10.1021/jf904227p

González-Torralva F, Gil-Humanes J, Barro F, Brants I, De Prado R (2012a) Target site mutation and reduced translocation are present in a glyphosate-resistant Lolium multiflorum Lam. biotype from Spain. Plant Physiol Biochem 58:16-22. doi:10.1016/j.plaphy.2012.06.001

González-Torralva F, Rojano-Delgado AM, Luque de Castro MD, Mülleder N, De Prado R (2012b) Two nontarget mechanisms are involved in glyphosate-resistant horseweed (Conyza canadensis L. Cronq.) biotypes. J Plant Physiol 169:1673-1679. doi:10.1016/ j.jplph.2012.06.014

Hao JH, Qiang S, Liu QQ, Cao F (2009) Reproductive traits associated with invasiveness in Conyza sumatrensis. J Syst Evol 47:245-254. doi:10.1111/j.1759-6831.2009.00019.x
Heap I (2013) International survey of herbicide resistant weeds. http:// www.weedscience.org. Accessed 16 Feb 2013

Hess M, Barralis G, Bleiholder H, Buhr L, Eggers T, Hack H, Stauss R (1997) Use of the extended BBCH scale - general for the descriptions of the growth stages of mono- and dicotyledonous weed species. Weed Res 37:433-441. doi:10.1046/j.1365-3180.1997.d01-70.x

Michitte P, De Prado R, Espinoza N, Ruiz-Santaella JP, Gauvrit C (2007) Mechanisms of resistance to glyphosate in a ryegrass (Lolium multiflorum) biotype from Chile. Weed Sci 55:435-440. doi:10.1614/WS-06-167.1

Nol N, Tsikou D, Eid M, Livieratos IC, Giannopolitis CN (2012) Shikimate leaf disc assay for early detection of glyphosate resistance in Conyza canadensis and relative transcript levels of EPSPS and $\mathrm{ABC}$ transporter genes. Weed Res 52:233-241. doi:10.1111/ j.1365-3180.2012.00911.x

Pline WA, Wilcut JW, Duke SO, Edmisten KL, Wells R (2002) Tolerance and accumulation of shikimic acid in response to glyphosate applications in glyphosate-resistant and nonglyphosateresistant cotton (Gossypium hirsutum L.). J Agric Food Chem 50:506-512. doi:10.1021/jf0110699

Recasens J, Conesa JA (2009) Malas hierbas en plántula: guía de identificación. Edicions de la Universitat de Lleida. Lleida, España

Salas RA, Dayan FE, Pan Z, Watson SB, Dickson JW, Scott RC, Burgos NR (2012) EPSPS gene amplification in glyphosate-resistant Italian ryegrass (Lolium perenne ssp. multiflorum) from Arkansas. Pest Manag Sci 68:1223-1230. doi:10.1002/ps.3342

Steinruecken HC, Amrhein N (1980) The herbicide glyphosate is a potent inhibitor of 5-enolpyruvyl-shikimic acid-3-phosphate synthase. Biochem Biophys Res Commun 94:1207-1212. doi:10.1016/ 0006-291X(80)90547-1

VanGessel MJ (2001) Glyphosate-resistant horseweed from Delaware. Weed Sci 49:703-705. doi:10.1614/0043-1745(2001)049[0703: RPRHFD]2.0.CO;2

Vila-Aiub MM, Balbi MC, Distéfano AJ, Fernández L, Hopp E, Yu Q, Powles SB (2012) Glyphosate resistance in perennial Sorghum halepense (Johnsongrass), endowed by reduced glyphosate translocation and leaf uptake. Pest Manag Sci 68:430-436. doi:10.1002/ ps. 2286

Walker S, Bell K, Robinson G, Widderick M (2011) Flaxleaf fleabane (Conyza bonariensis) populations have developed glyphosate resistance in north-east Australian cropping fields. Crop Prot 30:311-317. doi:10.1016/j.cropro.2010.11.010

Wang CJ, Liu ZQ (2007) Foliar uptake of pesticides - present status and future challenge. Pestic Biochem Physiol 87:1-8. doi:10.1016/ j.pestbp.2006.04.004

Yu Q, Abdallah I, Han H, Owen M, Powles S (2009) Distinct non-target site mechanisms endow resistance to glyphosate, ACCase and ALS-inhibiting herbicides in multiple herbicide-resistant Lolium rigidum. Planta 230:713-723. doi:10.1007/s00425-009-0981-8 